\title{
Article
}

\section{High versus Low-Moderate Intensity Exercise Training Program as an Adjunct to Antihypertensive Medication: A Pilot Clinical Study}

\author{
Vicente Ávila-Gandía ${ }^{1}, * \mathbb{D}$, Maravillas Sánchez-Macarro ${ }^{1} \oplus$, Antonio Luque-Rubia ${ }^{1}$, Esther García-Sánchez ${ }^{2}{ }^{\circledR}$, \\ Fernando Cánovas ${ }^{1} \mathbb{D}$, Asensio López-Santiago ${ }^{3}$ and Francisco Javier López-Román ${ }^{1,4} \mathbb{C}$ \\ 1 Department of Exercise Physiology, Universidad Católica de Murcia, 30107 Murcia, Spain; \\ msanchez4@ucam.edu (M.S.-M.); ajluque@ucam.edu (A.L.-R.); fcanovas@ucam.edu (F.C.); \\ jlroman@ucam.edu (F.J.L.-R.) \\ 2 Fundación para la Formación e Invetigación Sanitarias de la Región de Murcia, 30003 Murcia, Spain; \\ esther.garcia11@carm.es \\ 3 Servicio Murciano de Salud, 30120 Murcia, Spain; asensio.lopez@carm.es \\ 4 Primary Care Research GroupBiomedical Research Institute of Murcia (IMIB-Arrixaca), 30120 Murcia, Spain \\ * Correspondence: vavila@ucam.edu
}

check for updates

Citation: Ávila-Gandía, V.; Sánchez-Macarro, M.; Luque-Rubia, A.; García-Sánchez, E.; Cánovas, F.; López-Santiago, A.; López-Román, F.J High versus Low-Moderate Intensity Exercise Training Program as an Adjunct to Antihypertensive Medication: A Pilot Clinical Study. J. Pers. Med. 2021, 11, 291. https:// doi.org/10.3390/jpm11040291

Academic Editors: Andreas

P. Kalogeropoulos and

Konstantinos Tziomalos

Received: 3 March 2021

Accepted: 8 April 2021

Published: 10 April 2021

Publisher's Note: MDPI stays neutral with regard to jurisdictional claims in published maps and institutional affiliations.

Copyright: (c) 2021 by the authors. Licensee MDPI, Basel, Switzerland. This article is an open access article distributed under the terms and conditions of the Creative Commons Attribution (CC BY) license (https:/ / creativecommons.org/licenses/by/ $4.0 /)$.

\begin{abstract}
Objective: In this pilot clinical study we investigated the effect on blood pressure (BP) of two community-based exercise training programs of high (HIT) vs. low-moderate intensity (LMIT) in hypertensive individuals receiving at least one antihypertensive drug. Methods: The study included two phases of physical exercises based on 1-h session, 3 days/week for 12 and 16 weeks, respectively, separately by a 7-week resting period. Each phase was preceded by a four-week conditioning training period. According to the average maximal heart rate at baseline, participants were randomized to HIT (80-90\%), LMIT (50-70\%) or no-exercise (control). Heart rate was monitored during workout and BP profiles were registered by ambulatory BP monitoring at the beginning and end of each phase. Results: Of 60 individuals randomized, 44 completed the study (HIT, $n=10$; LMIT, $n=16$; controls, $n=18$ ). BP levels were significantly reduced after the second phase for both LMIT (SBP -3.1 $\mathrm{mmHg}$, DBP - 2.4 mmHg) and HIT (SBP $-10.8 \mathrm{mmHg}$, DBP $-8.3 \mathrm{mmHg}$ ). Similar levels of improvement were also found in daytime and night-time BP. Mean attendance of the prescribed training sessions was $87.4 \pm 6.2 \%$ for HIT and $87.4 \pm 5.3 \%$ for LMIT during the first phase and $84.1 \pm 5.0 \%$ and $85.2 \pm 5.9 \%$ during the second phase, respectively ( $p=0.047)$. Conclusion: Both HIT and LMIT exercise training programs reduced BP but the HIT modality showed a lower rate of compliance with proposed training schedule. Intensity of training should be individually prescribed to improve tolerance to more high intensity exercises.
\end{abstract}

Keywords: blood pressure monitoring; hypertension; physical exercises; primary care; training intensity

\section{Introduction}

Lifestyle modifications with weight-reducing diet, regular exercise, and restrict salt and alcohol intake are key strategies in the prevention and management of hypertension for the goal of reducing cardiovascular morbidity and mortality [1]. In adults with hypertension, different types of physical exercise training programs are able to reduce blood pressure (BP) [2,3], particularly resistance exercise training to reduce diastolic $\mathrm{BP}$ (DBP) $[2,4]$. Combined aerobic and resistance training are also effective to reduce BP in hypertensive adults [5,6], and endurance training has been shown to be successful in decreasing resting systolic BP (SBP) and DPB [7]. Although the mechanisms of the effects of exercise training are complex and not fully understood, emerging evidences suggest a relationship with the intensity of training (low-to-moderate vs. high) [8-10]. There is 
consensus regarding benefits and effectiveness of moderate or even less intensity exercise training $[9,10]$. However, high intensity interval training could lead to physiological adaptations that would contribute to reduce the risk of high BP [8].

Community-based interventions to promote physical activity in the general population have been a focus of increasing interest [11,12], and the European Society of Cardiology (ESC) and the European Society of Hypertension (ESH) [13] recommend a moderate intensity aerobic training for at least $30 \mathrm{~min}$ on most (preferably all) days of the week. However, there are still unsolved questions regarding the best type of exercise to be prescribed (e.g., aerobic, or resistance) and the adequate percentage of intensity about the maximum in order to obtain optimal health benefits [14]. Moreover, data are still unclear whether benefits are due to a higher volume of energy expended or as a result of a vigorous-intensity exercise training, although there are supporting evidences for the latter [15].

In a previous study, we have shown the feasibility and benefits of implementing a preventive physical exercise program prescribed by primary care physicians in cardiovascular risk patients, with improvements in anthropometric and fitness-related variables [16]. However, the effects on BP in the population of hypertensive patients were not evaluated. The present pilot study was designed to assess the effect on BP of two community-based exercise training programs of high (HIT) vs. low-moderate intensity (LMIT) in hypertensive individuals receiving at least one antihypertensive drug and without any previous history of regular physical training. Variations in BP were determined by ambulatory BP monitoring (ABPM) due to the design of two modalities of physical exercise programs, in which the intensity of training was the only variable at the same amount of volume of energy expended.

\section{Materials and Methods}

\subsection{Study Design and Population}

Between January 2016 and December 2019, a pilot clinical study was conducted at the Health Sciences Department of the Saint Anthony Catholic University in Murcia, Spain. The primary objective of the study was to assess the effects of an exercise training program intervention of different intensities (high intensity vs. low-moderate intensity) on lowering $\mathrm{BP}$ as an adjunct strategy in hypertensive individuals under treatment with at least one antihypertensive drug. All participants included in the study were referred by their primary care physicians who prescribed physical exercise as a healthy lifestyle intervention added to antihypertensive regimens in the framework of the "ACTIVA-Murcia Program" [16], which advocates for citizens involvement in health care by promoting behavioral and lifestyle healthy habits.

Eligible participants were males and females, aged 40 to 65 years old, diagnosed with hypertension, following an antihypertensive therapy with at least one drug of over 1-year treatment without changes in the prescription and without history of regular physical training. Exclusion criteria were severe or terminal illness, diagnosis of ischemic heart disease and/or cerebrovascular disease or any cardiovascular disease (e.g., peripheral artery disease), diseases that would limit the execution of aerobic or resistance exercises (musculoskeletal disorders, restrictive lung disease, arrhythmia), diabetes mellitus, severe mental disorder, pregnant or breast-feeding women, and incapacity to understand the informed consent.

The study protocol was approved by the Ethics Committee of Saint Anthony Catholic University, Murcia (Spain). All participants gave written informed consent.

\subsection{Physical Training Program}

The same exercise training program was followed by all participants, with the only difference being the intensity of training. The program included two phases of physical exercises of 12 weeks (from 20 September 2016 to 23 December 2016) and 16 weeks (from 4 February 2017 to 12 June 2017) duration, respectively, separated by a 7-week resting 
period, which was coincident with a vacation period. The physical training program was carried out 3 days a week in 1-h sessions. Minimum compliance was considered, estimating attendance of $66 \%$ of the sessions as suitable threshold for completion of the training program. Each participant was randomized to one of three study groups of high intensity training (HIT), low-moderate intensity training (LMIT) or no-training (control) in a 1:1:1 ratio using Epidata software version 4.0, (EpiData Association, Odense, Denmark).

The intensity of training was established at one baseline session of aerobic exercise testing on a treadmill following a modification of the Balke-Ware protocol [17] but using the same protocol for men and women [18]. Warm up exercise was developed previous to the test during $2 \mathrm{~min}$ : first minute at a speed of $3 \mathrm{~km} / \mathrm{h}$ and $1.5 \%$ slope, and second minute at $4 \mathrm{~km} / \mathrm{h}$ and $4 \%$ slope. Test was divided into 15 phases of 1 min each with increments of speed $(0.2 \mathrm{~km} / \mathrm{h})$ and slope $(1 \%)$, starting at a speed of $5 \mathrm{~km} / \mathrm{h}$ and $5 \%$ slope. All participants were monitored by ECG and gas analyzer (Jaeger Oxicom Pro ${ }^{\circledR}$, Jaeger, Wuerzburg, Germany) in order to determine the maximum heart rate (MHR) and monitor heart rate (HR) above anaerobic threshold and during maximal oxygen uptake (VO2 max).

The physical training program was carried out 3 days a week in 1-h sessions focused on basic exercises of endurance (Global bodily activities), strength (Activities specific muscle regions) and flexibility. Physical activity was based on standardized fitness and wellness training and adapted to hypertensive patients by reducing intensity and applying restriction of movements. The program was developed by graduates in Sciences of Physical Activity and Sports, who were responsible for teaching the exercises and supervised every training session. Sessions were structured in blocks that provided a dynamic combination of exercises, avoiding an extended process of routine learning. As shown in Table 1, each session included a warm up with muscular activation, articular mobility and stretching exercises; an aerobic exercise interval at the desired HR target according to MHR recorded at the baseline aerobic exercise testing; and a final cool down based on stretching exercises. HR was monitored using a pulsometer (Polar RS400, Polar Electro Oy, Kempele, Finland) and loads of the exercises were targeted at $80-90 \%$ of MHR for the HIT group and at $50-70 \%$ of HR for the LMIT group. HR recordings were stored and analyzed for later assessment of adherence to intensity of the corresponding training program. Participants assigned to the HIT and LMIT groups received guidelines to continue physical exercise during the 7-week resting period, whereas participants in the control group were offered participation in the program after the study.

The course of the study is shown in Figure 1.

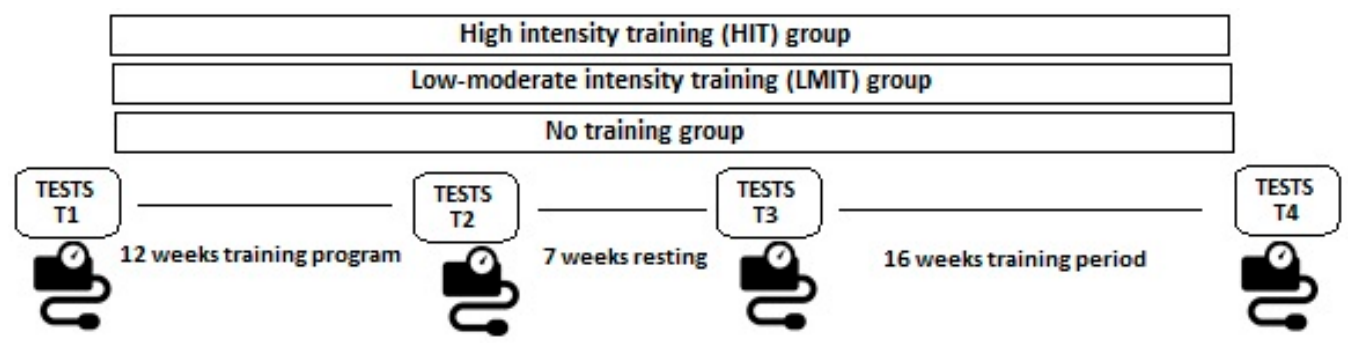

Figure 1. Participants were assigned to HIT, LMIT or no training groups, and the program included a first 12-week training phase followed by a 7-week resting period, and a 16-week training phase. 
Table 1. Main characteristics of the training program.

\begin{tabular}{|c|c|c|c|c|c|c|c|c|}
\hline \multirow{2}{*}{ Block } & \multirow{2}{*}{ Aim } & \multirow{2}{*}{ Type } & \multirow{2}{*}{ Exercises } & \multirow{2}{*}{$\begin{array}{l}\text { Duration } \\
\text { min }\end{array}$} & \multicolumn{2}{|c|}{ LMIT, Intensity \% } & \multicolumn{2}{|c|}{ HIT, Intensity \% } \\
\hline & & & & & Time & MHR & Time $\%$ & MHR \\
\hline Warm up & $\begin{array}{l}\text { Flexibility } \\
\text { and mobility }\end{array}$ & Warm up & $\begin{array}{l}\text { Deep inspirations, } \\
\text { general stretching by } \\
\text { muscular groups }\end{array}$ & $4-8$ & & & & \\
\hline Aerobic \#1 & $\begin{array}{c}\mathrm{CV} \\
\text { endurance }\end{array}$ & Intervals & $\begin{array}{c}\text { Grapevines, boxing, } \\
\text { kicks }\end{array}$ & 22 & 38 & 60 & 38 & 85 \\
\hline Aerobic \#2 & $\begin{array}{c}\mathrm{CV} \\
\text { endurance }\end{array}$ & Constant & Grapevines, kicks & 22 & 20 & 55 & 20 & 80 \\
\hline $\begin{array}{l}\text { Tone up } \\
\text { muscles }\end{array}$ & $\begin{array}{l}\text { Muscle } \\
\text { strength }\end{array}$ & Series & $\begin{array}{l}\text { Elbow flexion, } \\
\text { abdominal } \\
\text { contractions, squats }\end{array}$ & 10 & 20 & 70 & 20 & 90 \\
\hline $\begin{array}{l}\text { Strength } \\
\text { and } \\
\text { endurance }\end{array}$ & $\begin{array}{c}\text { Muscle } \\
\text { strength and } \\
\text { CV } \\
\text { endurance }\end{array}$ & Intervals & $\begin{array}{l}\text { Elbow flexion, } \\
\text { abdominal } \\
\text { contractions, squats, } \\
\text { side shoulder } \\
\text { elevation, scissor }\end{array}$ & 12 & 11 & 60 & 11 & 75 \\
\hline $\begin{array}{l}\text { Race } \\
\text { technique }\end{array}$ & $\begin{array}{c}\text { Muscle } \\
\text { strength and } \\
\text { CV } \\
\text { endurance }\end{array}$ & Intervals & $\begin{array}{l}\text { Standing hamstring } \\
\text { curl, side jumps, } \\
\text { long steps, knee-up }\end{array}$ & 5 & 5 & 60 & 5 & 80 \\
\hline \multicolumn{4}{|c|}{ Average intensity \% MHR } & & \multicolumn{2}{|c|}{61.55} & \multicolumn{2}{|c|}{82.8} \\
\hline
\end{tabular}

LMIT: low-moderate intensity training; HIT: high intensity training; MHR: maximum heart rate; CV: cardiovascular.

\subsection{Data Collection}

BP profiles were assessed by ABPM and recorded at the beginning (time \#1, T1) and at the end of the first 12-week intervention phase of the study (time \#2, T2), at week 19 after the 7-week resting period and prior to the beginning the second 16-week intervention phase (time \#3, T3) and at week 35 at the end of the study (time \#4, T4). Forty-eight hours after the last training sessions for every cited period, each patient was given a 24-h oscilometric blood pressure monitor device (Spacelabs Healthcare ABP monitor model 90217A, Spacelabs Medical Inc., Redmond, WA, USA) with the cuff width encircling 40\% of the arm circumference and cuff length at least $80-100 \%$. BP was measured at intervals of 30 min during the day and 60 min at night. Participants filled a logbook about relevant aspects of daily life (hours of labor, diet, sleeping hours, and habits) in order to synchronize BP monitor records with day activity and resting time. Night-time period was considered from 22:00 p.m. to 6:00 a.m. An entry was only considered valid when more than $70 \%$ of data were properly recorded, adding a minimum of 20 daytime readings and 7 night-time readings. Observations were then summarized as mean and standard deviation $( \pm \mathrm{SD})$ as well as the difference of increment from baseline for systolic BP (SBP), diastolic BP (DBP), and pulse pressure (PP) during daytime, night-time and overall. Mean arterial pressure (MAP) was calculated as DBP $+1 / 3$ PP. Systolic and diastolic load were estimated as the percentage of $\mathrm{BP}$ readings above reference values of SBP and DBP, respectively [13].

\subsection{Statistical Analysis}

The analysis of variance (ANOVA) for repeated measures was used to compare BP variables derived from ABPM profiles that were obtained at the beginning and end of the two defined phases of the trial. All variables were checked for normality. Homogeneity of variables among groups was also checked at baseline in order to avoid confounder variables. Training intensity (HIT, LMIT, and control) was included as an inter-subject factor in the analyses. Bonferroni correction was used for all comparisons between intervention groups and control. Type I error rate was set at $\alpha=0.05$. The per-protocol (PP) data set 
was analyzed. Analyses were also performed in the intention-to-treat (ITT) population. The SPSS statistical software v.21.0 (IBM Corp., Armonk, NY, USA) was used for the analysis of data.

\section{Results}

A total of 90 subjects were assessed for eligibility, 25 of whom did not meet the inclusion criteria and 5 refused to participate. The study population included 60 hypertensive subjects, 20 of which were randomly assigned to each study group. However, $44(73.3 \%)$ participants (19 men, 25 women; mean age 56.4 years) completed the study (minimum compliance of $66 \%$ of training sessions during the programmed sessions) (HIT, $n=10$; LMIT, $n=16$; controls, $n=18$ ). The distribution by gender (females) showed no significant differences (chi-square test, $p=0.814$ ). The flow chart of the study population is shown in Figure 2.

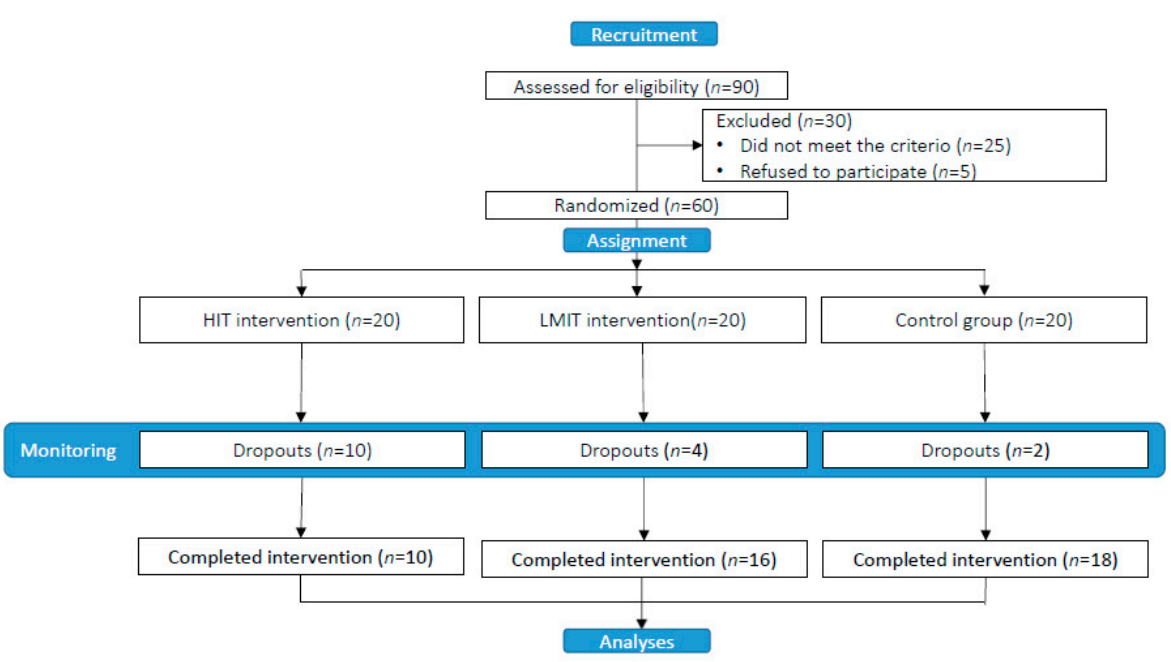

Figure 2. Flow chart of the study population.

There were no statistically significant differences in age, BMI, lean body mass, fat body mass, SBP, and DBP when baseline values and values obtained at the end of the study were compared for either within-group or between-group differences (Table 2).

Anti-hypertensive pharmacological treatment included angiotensin receptor blockers in $42.5 \%$, diuretics in $23.4 \%$, beta-blockers in $14.9 \%$, calcium antagonists in $10.6 \%$, angiotensin-converting enzyme inhibitors in $6.4 \%$, and alpha-blockers in $2.2 \%$. In two patients assigned to the HIT group, the dose of beta-blockers was reduced by their primary care physician during the study. Differences in anti-hypertensive treatment by groups were not found (Table 3).

No statistically significant differences in 24-h ABPM variables for any group between the beginning (T1) and the end (T2) of the first 12-week phase of the study were observed (Table 3). During the second intervention phase of the study, mean decreases in SBP ( $-3.1 \mathrm{mmHg}, 95 \% \mathrm{CI}-6.7$ to 0.6$)$, DBP $(-2.4 \mathrm{mmHg}$, 95\% CI -4.4 to -0.5$)$, systolic load $(-6.2 \%)$, and diastolic load $(-8.6 \%)$ observed in the LMIT were not statistically significant. However, all these changes in the HIT group were significant $(p<0.001)$, with mean decreases of SBP of $-10.8 \mathrm{mmHg}(95 \% \mathrm{CI}-15.4$ to -6.2$)$, DBP of $-8.3 \mathrm{mmHg}(95 \% \mathrm{CI}$ -10.8 to -5.8 ), systolic load of $-27.0 \%$, and diastolic load of $-26.9 \%$ (Table 4 ). Similar results were obtained in the ITT analysis (see Table S1 in the Supplementary Materials). 
Table 2. Demographic and clinical characteristics of the 60 hypertensive subjects who were randomized and 44 who completed the study.

\begin{tabular}{|c|c|c|c|c|c|c|c|c|c|}
\hline \multirow{2}{*}{ Variables } & \multicolumn{3}{|c|}{ High Intensity Training Group } & \multicolumn{3}{|c|}{$\begin{array}{l}\text { Low-Moderate Intensity } \\
\text { Training Group }\end{array}$} & \multicolumn{3}{|c|}{ Control Group } \\
\hline & $\begin{array}{l}\text { Baseline } \\
(n=20)\end{array}$ & $\begin{array}{l}\text { Study End } \\
(n=10)\end{array}$ & $\begin{array}{l}\text { Dropout } \\
(n=10)\end{array}$ & $\begin{array}{l}\text { Baseline } \\
(n=20)\end{array}$ & $\begin{array}{l}\text { Study End } \\
(n=16)\end{array}$ & $\begin{array}{l}\text { Dropout } \\
(n=4)\end{array}$ & $\begin{array}{l}\text { Baseline } \\
(n=20)\end{array}$ & $\begin{array}{l}\text { Study End } \\
\quad(n=18)\end{array}$ & $\begin{array}{l}\text { Dropout } \\
(n=2)\end{array}$ \\
\hline Age, years & $54.2 \pm 7.8$ & $53.5 \pm 7.5$ & $55.0 \pm 8.4$ & $55.5 \pm 6.3$ & $56.1 \pm 6.4$ & $53.5 \pm 5.8$ & $60.0 \pm 7.4$ & $59.3 \pm 8.2$ & $61.0 \pm 4.2$ \\
\hline$p$ value & \multicolumn{2}{|c|}{0.784} & & \multicolumn{2}{|c|}{0.833} & \multicolumn{4}{|c|}{0.950} \\
\hline $\begin{array}{c}\mathrm{BMI} \\
\mathrm{kg} / \mathrm{m}^{2}\end{array}$ & $30.1 \pm 3.9$ & $30.4 \pm 4.2$ & $28.6 \pm 3.2$ & $30.1 \pm 3.9$ & $30.4 \pm 4.2$ & $29.0 \pm 2.5$ & $27.9 \pm 4.0$ & $28.2 \pm 4.3$ & $29.0 \pm 2.5$ \\
\hline$p$ value & \multicolumn{2}{|c|}{0.995} & & \multicolumn{2}{|c|}{0.835} & \multicolumn{4}{|c|}{0.882} \\
\hline $\begin{array}{l}\text { Lean body } \\
\text { mass, } \mathrm{kg}\end{array}$ & $50.3 \pm 8.2$ & $48.9 \pm 10.8$ & $51.7 \pm 4.7$ & $47.9 \pm 9.7$ & $48.6 \pm 10.1$ & $45.1 \pm 7.4$ & $45.6 \pm 8.4$ & $45.1 \pm 8.9$ & $47.8 \pm 7.1$ \\
\hline$p$ value & \multicolumn{2}{|c|}{0.878} & & \multicolumn{2}{|c|}{0.823} & \multicolumn{4}{|c|}{0.912} \\
\hline $\begin{array}{l}\text { Fat body } \\
\text { mass, kg }\end{array}$ & $27.5 \pm 8.6$ & $27.6 \pm 9.3$ & $26.6 \pm 7.6$ & $31.6 \pm 9.2$ & $32.7 \pm 9.6$ & $27.4 \pm 6.3$ & $27.3 \pm 7.6$ & $28.5 \pm 7.5$ & $21.2 \pm 7.1$ \\
\hline$p$ value & \multicolumn{2}{|c|}{0.979} & & \multicolumn{2}{|c|}{0.716} & \multicolumn{4}{|c|}{0.746} \\
\hline $\begin{array}{l}\text { Systolic BP, } \\
\text { mmHg }\end{array}$ & $131.2 \pm 9.1$ & $131.5 \pm 12.3$ & $131.0 \pm 4.8$ & $128.6 \pm 7.7$ & $128.6 \pm 8.3$ & $128.2 \pm 5.7$ & $126.7 \pm 9.7$ & $126.2 \pm 10.2$ & $129.0 \pm 9.9$ \\
\hline$p$ value & \multicolumn{2}{|c|}{0.921} & & \multicolumn{2}{|c|}{0.978} & \multicolumn{4}{|c|}{0.907} \\
\hline $\begin{array}{l}\text { Diastolic } \\
\mathrm{BP}, \mathrm{mmHg}\end{array}$ & $80.9 \pm 6.0$ & $81.3 \pm 7.3$ & $80.5 \pm 4.6$ & $79.7 \pm 4.7$ & $79.9 \pm 4.4$ & $78.8 \pm 6.5$ & $78.3 \pm 9.2$ & $77.7 \pm 9.8$ & $81.5 \pm 6.3$ \\
\hline$p$ value & \multicolumn{2}{|c|}{0.878} & & \multicolumn{2}{|c|}{0.920} & \multicolumn{4}{|c|}{0.826} \\
\hline
\end{tabular}

Table 3. Antihypertensive medication in the three study groups.

\begin{tabular}{|c|c|c|c|c|c|c|}
\hline & \multicolumn{6}{|c|}{ Antihypertensive Pharmacological Treatment } \\
\hline & ACE Inhibitors & ARB & $\alpha$-Blockers & $\beta$-Blockers & $\begin{array}{c}\text { Calcium } \\
\text { Antagonists }\end{array}$ & Diuretics \\
\hline Control group, $n(\%)$ & $2(10.0)$ & $13(65.0)$ & $0(0)$ & $3(15.0)$ & $5(24.9)$ & $5(24.9)$ \\
\hline LMIT, $n(\%)$ & $2(10.0)$ & $15(75.0)$ & $0(0)$ & $5(24.9)$ & $3(15.0)$ & $7(35.0)$ \\
\hline $\mathrm{HIT}, n(\%)$ & $2(10.0)$ & $9(45.0)$ & $2(10.0)$ & $3(15.0)$ & $0(0)$ & $3(15.0)$ \\
\hline Total, $n(\%)$ & $6(10.0)$ & $37(61.7)$ & $2(3.3)$ & $11(18.3)$ & $8(13.3)$ & $15(25.0)$ \\
\hline$p$ value & 1.0 & 0.139 & 0.246 & 0.641 & 0.245 & 0.344 \\
\hline
\end{tabular}

Data are reported as n (number) and \% (percentage of the total for each group); ACE inhibitors: angiotensin-converting enzyme inhibitors; ARB: angiotensin receptor blockers; $p$ value for between-group comparison with the chi-square test with each of these treatments. 
Table 4. Summary of data from ABPM recordings overall $24 \mathrm{~h}$.

\begin{tabular}{|c|c|c|c|c|c|c|c|c|c|}
\hline Variable & Group & T1 ( \pm SD) & $\Delta \mathrm{T} 2-\mathrm{T} 1(95 \% \mathrm{CI})$ & T3 ( \pm SD) & $\Delta \mathrm{T} 4-\mathrm{T} 3(95 \% \mathrm{CI})$ & $\Delta \mathrm{T} 4-\mathrm{T} 1(95 \% \mathrm{CI})$ & $P_{\mathrm{T} 2-\mathrm{T} 1}$ & $P_{\mathrm{T} 4-\mathrm{T} 3}$ & $P_{\mathrm{T} 4-\mathrm{T} 1}$ \\
\hline \multirow{3}{*}{$\begin{array}{c}\text { Average SBP } \\
(\mathrm{mmHg})\end{array}$} & Control & $126.2 \pm 10.2$ & $0.2(-3.7$ to 4.1$)$ & $125.1 \pm 9.4$ & $1.4(-3.2$ to 6.0$)$ & $0.3(-4.0$ to 4.6$)$ & \multirow{3}{*}{0.860} & \multirow{3}{*}{$<0.001$} & \multirow{3}{*}{$<0.001$} \\
\hline & LMIT & $128.7 \pm 8.3$ & $1.1(-2.0$ to 4.2$)$ & $130.1 \pm 10.4$ & $-3.1(-6.7$ to 0.6$)$ & $-1.6(-5.0$ to 1.7$)$ & & & \\
\hline & HIT & $131.5 \pm 12.3$ & $0.3(-3.6$ to 4.2$)$ & $134.0 \pm 12.7$ & $-10.8(-15.4$ to -6.2$) *+\ddagger$ & $-8.3(-12.6 \text { to }-4.0)^{*}$ & & & \\
\hline \multirow{3}{*}{$\begin{array}{l}\text { Average DBP } \\
\quad(\mathrm{mmHg})\end{array}$} & Control & $77.7 \pm 9.8$ & $0.3(-2.7$ to 3.3$)$ & $78.7 \pm 9.6$ & $-0.3(-2.8$ to 2.1$)$ & $0.7(-2.7$ to 4.1$)$ & \multirow{3}{*}{0.611} & \multirow{3}{*}{$<0.001$} & \multirow{3}{*}{$<0.00$} \\
\hline & LMIT & $79.9 \pm 4.4$ & $0.9(-1.5$ to 3.3$)$ & $81.3 \pm 5.6$ & $-2.4(-4.4 \text { to }-0.5)^{*}$ & $-1.1(-3.7$ to 1.6$)$ & & & \\
\hline & HIT & $81.3 \pm 7.3$ & $-0.5(-3.5$ to 2.5$)$ & $83.4 \pm 7.0$ & $-8.3(-10.8$ to -5.8$) *+\ddagger$ & $-6.2(-9.6$ to -2.8$)$ * & & & \\
\hline \multirow{3}{*}{$\begin{array}{l}\text { Average MAP } \\
\quad(\mathrm{mmHg})\end{array}$} & Control & $93.9 \pm 9.3$ & $0.3(-2.8$ to 3.3$)$ & $94.2 \pm 9.1$ & $0.3(-2.7$ to 3.2$)$ & $0.6(-2.8$ to 3.9$)$ & \multirow{3}{*}{0.688} & \multirow{3}{*}{$<0.001$} & \multirow{3}{*}{$<0.00$} \\
\hline & LMIT & $96.1 \pm 4.7$ & $0.9(-1.4$ to 3.3$)$ & $97.5 \pm 6.8$ & $-2.6(-5.0$ to -0.3$) *$ & $-1.3(-3.9$ to 1.4$)$ & & & \\
\hline & HIT & $98.0 \pm 7.4$ & $-0.2(-3.3$ to 2.8$)$ & $100.3 \pm 7.7$ & $-9.1(-12.1$ to -6.2$) *+\ddagger$ & $-6.9(-10.2$ to -3.5$) *$ & & & \\
\hline \multirow{3}{*}{$\begin{array}{l}\text { Average PP } \\
(\mathrm{mmHg})\end{array}$} & Control & $48.5 \pm 7.5$ & $-0.1(-3.2$ to 3.0$)$ & $48.4 \pm 7.1$ & $0.1(-3.1$ to 3.3$)$ & $-0.4(-3.6$ to 2.8$)$ & \multirow{3}{*}{0.838} & \multirow{3}{*}{0.248} & \multirow{3}{*}{0.658} \\
\hline & LMIT & $48.8 \pm 8.0$ & $0.2(-2.2$ to 2.6$)$ & $49.0 \pm 8.1$ & $-0.6(-3.1$ to 1.8$)$ & $-0.6(-3.1$ to 2.0$)$ & & & \\
\hline & HIT & $50.2 \pm 12.0$ & $0.8(-2.3$ to 3.9$)$ & $51.0 \pm 12.3$ & $-2.5(-5.7$ to 0.7$)$ & $-2.1(-5.3$ to 1.1$)$ & & & \\
\hline \multirow{2}{*}{$\begin{array}{l}\text { SD of SBP } \\
(\mathrm{mmHg})\end{array}$} & Control & $11.9 \pm 3.2$ & $-0.8(-3.5$ to 1.9$)$ & $11.9 \pm 3.0$ & $-1.0(-3.3$ to 1.3$)$ & $-1.1(-3.5$ to 1.4$)$ & \multirow[b]{2}{*}{0.243} & \multirow[b]{2}{*}{0.275} & \multirow[b]{2}{*}{0.073} \\
\hline & LMIT & $12.7 \pm 3.3$ & $-0.3(-2.4$ to 1.9$)$ & $12.3 \pm 3.0$ & $-0.8(-2.6$ to 1.0$)$ & $-1.2(-3.2$ to 0.8$)$ & & & \\
\hline \multirow{3}{*}{$\begin{array}{l}\text { SD of DBP } \\
(\mathrm{mmHg})\end{array}$} & Control & $9.9 \pm 2.5$ & -0.5 (-3.1 to 2.2$)$ & $9.5 \pm 1.6$ & $0.3(-1.4$ to 2.0$)$ & $-0.1(-2.2$ to 2.0$)$ & \multirow{3}{*}{0.267} & \multirow{3}{*}{0.077} & \multirow{3}{*}{0.146} \\
\hline & LMIT & $11.2 \pm 2.1$ & $-1.1(-3.2$ to 1.0$)$ & $10.0 \pm 2.4$ & $-0.3(-1.6$ to 1.0$)$ & $-1.4(-3.1$ to 0.2$)$ & & & \\
\hline & HIT & $11.1 \pm 1.8$ & $0.9(-1.8$ to 3.5$)$ & $11.4 \pm 2.7$ & $-1.7(-3.3$ to 0.1$)$ & $-1.3(-3.4$ to 0.8$)$ & & & \\
\hline \multirow{3}{*}{$\begin{array}{c}\text { Systolic load } \\
(\%)\end{array}$} & Control & $35.1 \pm 26.0$ & $-2.4(-10.2$ to 5.4$)$ & $34.4 \pm 25.9$ & $-0.6(-14.8$ to 13.6$)$ & $-1.3(-16.5$ to 13.9$)$ & \multirow{3}{*}{0.504} & \multirow{3}{*}{$<0.05$} & \multirow{3}{*}{$<0.05$} \\
\hline & LMIT & $44.3 \pm 25.9$ & $1.1(-5.1$ to 7.3$)$ & $45.4 \pm 29.6$ & $-6.2(-17.4$ to 5.0$)$ & $-5.2(-17.2$ to 6.8$)$ & & & \\
\hline & HIT & $59.8 \pm 28.9$ & $-2.3(-10.2$ to 5.5$)$ & $59.7 \pm 25.1$ & $-27.0(-41.2$ to -12.8$) *+\ddagger$ & $-27.0(-42.2$ to -11.9$) *$ & & & \\
\hline \multirow{3}{*}{ Diastolic load (\%) } & Control & $36.3 \pm 27.2$ & $0.5(-16.7$ to 17.7$)$ & $35.0 \pm 26.5$ & $0.8(-12.2$ to 13.8$)$ & $-0.6(-55.6$ to 54.4$)$ & \multirow{3}{*}{0.334} & \multirow{3}{*}{$<0.05$} & \multirow{3}{*}{0.148} \\
\hline & LMIT & $45.8 \pm 16.6$ & $1.7(-11.9$ to 15.4$)$ & $50.4 \pm 22.1$ & $-8.6(-19.0$ to 1.6$)$ & $-4.1(47.6$ to 39.4$)$ & & & \\
\hline & HIT & $88.4 \pm 116.1$ & $-9.6(-26.8$ to 7.7$)$ & $54.9 \pm 21.5$ & $-26.9(-40.0$ to -14.0$) *+\ddagger$ & $-60.5(-115.5$ to -5.5$) *$ & & & \\
\hline
\end{tabular}

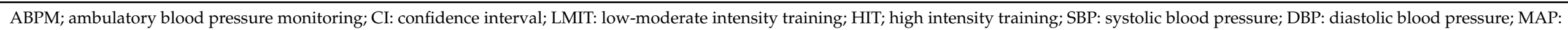

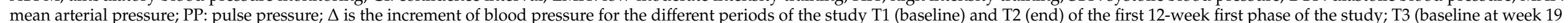

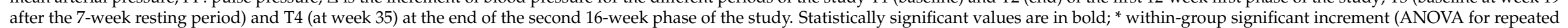
measures group and time); ${ }^{\dagger}$ between-group significant increment (training vs. control groups); ${ }^{\ddagger}$ between-group significant increment (LMIT vs. HIT). Dropouts, $n=44$, are excluded. 
Changes in daytime AMBP variables showed a similar profile than 24-h recordings (Table 5), with statistically significant differences in decreases of average SBP $(-11.2 \mathrm{mmHg})$, average DBP $(-8.2 \mathrm{mmHg}), \mathrm{MAP}(-9.2 \mathrm{mmHg})$, systolic load $(-24.4 \%)$, and diastolic load $(-27.3 \%)$ in the second phase of the study for the HIT group only. In the night-time AMBP recordings (Table 6), similar findings were found in the HIT group, with significant reductions of average SBP $(-9.5 \mathrm{mmHg}), \mathrm{DBP}(-7.0 \mathrm{mmHg}), \mathrm{MAP}(-7.8 \mathrm{mmHg})$, systolic load $(-35.9 \%)$, and diastolic load $(-26.6 \%)$ during the second phase of the study. Differences between beginning of the first phase of the study and at the study end were also observed in average SBP $(-7.4 \mathrm{mmHg})$ and MAP $(-6.1 \mathrm{mmHg})$.

Average compliance was $86 \%$ of training sessions (range $79 \%$ to $100 \%$ ). During the first 12-week phase of the study, subjects attended to $87.4 \pm 5.3 \%$ of LMIT sessions and $87.4 \pm 6.2 \%$ of HIT sessions. Attendance decreased during the second 16-week phase of the study $(85.2 \pm 5.9 \%$ and $84.1 \pm 5.0 \%$ of sessions for LMIT and HIT programs, respectively). Two subjects from the control group withdrawn from the trial. Four subjects from the LMIT program did not complete this program (66\% of the sessions). However, $10(50 \%)$ patients assigned to the HIT group attended less than $66 \%$ of the sessions. There were significant differences in compliance rate between the three study groups $(p=0.012)$, with significant differences between the LMIT and HIT groups $(p=0.047)$

Two different intensity training programs with intervals of aerobic exercises were evaluated in hypertensive subjects already treated with antihypertensive medication and recruited in the primary care setting. The study included two separate phases of $1-\mathrm{h}$ sessions, three times a week, over 12 and 16 weeks, respectively, with a resting period of 7 weeks overlapping vacation period. The effects of interrupting training activities on potential lifestyle changes, loss of improvement in cardiovascular parameters, or attendance to the second phase of the study have not been evaluated.

An interesting finding was a higher compliance with this training program in the LMIT group compared to the HIT group, in which half of the patients dropped out. Such observation could be indicating a lower adherence to the HIT program. Therefore, significant improvements in BP observed in the HIT group vs. slight improvements in the LMTI group were penalized by a higher withdrawal rate. In overweight and obese adults, it has been reported that high intensity interval training and moderate-intensity continuous training showed no differences in exercise adherence after eight weeks [19]. In relation to the optimal intensity of the exercise for inducing a sustained weight or fat-mass loss in overweight/obese people, HIT appears to induce superior improvements in aerobic fitness, but decreases adherence and results in the completion of less exercise [20]. In fact, response to physical exercise could determine adherence to a training program in direct association with the degree of unpleasant perception of the tasks performed, particularly when they are developed close to fatigue [21,22]. Therefore, a pleasant sensation related with physical exercise practice is reduced when its intensity is above the anaerobic threshold probably due to the accumulation of lactate in blood and musculoskeletal tissues, so that exceeding the anaerobic threshold could affect negatively pleasant sensations [23,24]. By contrast, individualized training prescription with progressive increase of intensity may be a critical factor to improve tolerance $[25,26]$, particularly in community-based programs addressed to sensitive patients (e.g., advanced age, and under pharmacological treatment). In a randomized study in which sedentary young adults were assigned to six weeks of HIT or moderate continuous training, enjoyment for HIT increased with training whereas enjoyment for moderate continuous training remained constant and lower [27]. 
Table 5. Summary of data from ABPM recordings during daytime.

\begin{tabular}{|c|c|c|c|c|c|c|c|c|c|}
\hline Variable & Group & $\mathrm{T1}$ ( $\pm \mathrm{SD})$ & $\Delta \mathrm{T} 2-\mathrm{T} 1(95 \% \mathrm{CI})$ & T3 ( \pm SD) & $\Delta \mathrm{T} 4-\mathrm{T} 3(95 \% \mathrm{CI})$ & $\Delta \mathrm{T} 4-\mathrm{T} 1(95 \% \mathrm{CI})$ & $P_{\mathrm{T} 2-\mathrm{T} 1}$ & $P_{\mathrm{T} 4-\mathrm{T} 3}$ & $P_{\mathrm{T} 4-\mathrm{T} 1}$ \\
\hline \multirow{3}{*}{$\begin{array}{l}\text { Average SBP } \\
\text { (mmHg) }\end{array}$} & Control & $128.1 \pm 9.1$ & $0.2(-4.5$ to 4.9$)$ & $127.9 \pm 8.9$ & $-0.2(-5$ to 4.5$)$ & $-0.4(-5.2$ to 4.4$)$ & \multirow{3}{*}{0.995} & \multirow{3}{*}{$<0.001$} & \multirow{3}{*}{$<0.001$} \\
\hline & LMIT & $132.3 \pm 8.2$ & $0.0(-3.7$ to 3.7$)$ & $132.5 \pm 10.1$ & $-3.6(-7.3$ to 0.2$)$ & $-3.4(-7.2$ to 0.4$)$ & & & \\
\hline & HIT & $134.7 \pm 12.5$ & $0.0(-4.7$ to 4.7$)$ & $137.2 \pm 13.9$ & $-11.2(-16.0$ to -6.4$) *+\ddagger$ & $-8.7(-13.5 \text { to }-0.4)^{*}$ & & & \\
\hline \multirow{3}{*}{$\begin{array}{l}\text { Average DBP } \\
(\mathrm{mmHg})\end{array}$} & Control & $79.6 \pm 10.0$ & $-0.2(-4.4$ to 4.0$)$ & $79.8 \pm 10.0$ & $-0.4(-3.2$ to 2.4$)$ & $-0.2(-3.7$ to 3.3$)$ & \multirow{3}{*}{0.720} & \multirow{3}{*}{$<0.001$} & \multirow{3}{*}{$<0.00$} \\
\hline & LMIT & $83.4 \pm 4.8$ & $0.3(-3.1$ to 3.6$)$ & $83.9 \pm 6.0$ & $-2.4(-4.6 \text { to }-0.3)^{*}$ & $-2.0(-4.7$ to 0.8$)$ & & & \\
\hline & HIT & $84.5 \pm 7.5$ & $-1.3(-5.5$ to 2.9$)$ & $86.2 \pm 7.5$ & $-8.2(-11.0$ to -5.4$) *+\ddagger$ & $-6.5(-10.0$ to -3.0$) *$ & & & \\
\hline \multirow{2}{*}{$\begin{array}{l}\text { Average MAP } \\
\quad(\mathrm{mmHg})\end{array}$} & LMIT & $99.7 \pm 4.9$ & $0.2(-3.0$ to 3.3$)$ & $100.1 \pm 6.9$ & $-2.8(-5.4 \text { to }-0.2)^{*}$ & $-2.4(-5.3$ to 0.4$)$ & & & \\
\hline & HIT & $101.2 \pm 7.6$ & $-0.9(-4.9$ to 3.1$)$ & $103.2 \pm 8.4$ & $-9.2(-12.5$ to -5.9$) *+\ddagger$ & $-7.2(-10.8$ to -3.6$) *$ & & & \\
\hline \multirow{3}{*}{ Systolic load (\%) } & Control & $31.2 \pm 25.7$ & $-1.7(-17.7$ to 14.4$)$ & $31.0 \pm 25.7$ & $-1.1(-17.5$ to 15.3$)$ & $-1.4(-18.3$ to 15.5$)$ & \multirow{3}{*}{0.335} & \multirow{3}{*}{$<0.05$} & \multirow{3}{*}{$<0.05$} \\
\hline & LMIT & $40.1 \pm 27.2$ & $0.9(-11.7$ to 13.6$)$ & $40.7 \pm 31.1$ & $-8.7(-21.6$ to 4.3$)$ & $-8.1(-21.4$ to 5.3$)$ & & & \\
\hline & HIT & $56.7 \pm 28.4$ & $-9.9(-25.9$ to 6.2$)$ & $53.6 \pm 33.4$ & $-24.4(-40.8$ to -8.0$) * t$ & $-27.5(-44.4$ to -10.6$) *$ & & & \\
\hline \multirow[b]{2}{*}{ Diastolic load (\%) } & Control & $26.9 \pm 26.1$ & $1.6(-17.4$ to 20.6$)$ & $27.3 \pm 27.2$ & $1.2(-13.1$ to 15.4$)$ & $1.6(-16.2$ to 19.4$)$ & \multirow[b]{2}{*}{0.512} & \multirow[b]{2}{*}{$<0.005$} & \multirow[b]{2}{*}{$<0.05$} \\
\hline & LMIT & $40.7 \pm 18.6$ & $1.4(-13.6$ to 16.4$)$ & $45.6 \pm 23.1$ & $-9.9(-21.2$ to 1.4$)$ & $-5(-19.1$ to 9.1$)$ & & & \\
\hline
\end{tabular}

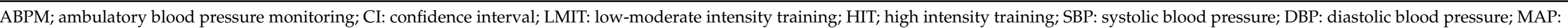

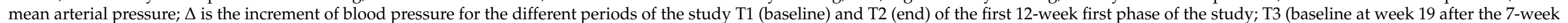

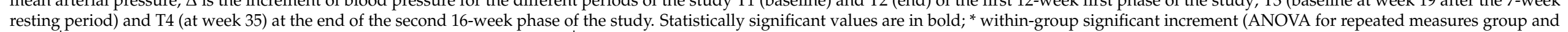
time); ${ }^{+}$between-group significant increment (training vs. control groups); ${ }^{\ddagger}$ between-group significant increment (LMIT vs. HIT). 
Table 6. Summary of data from ABPM recordings during night-time.

\begin{tabular}{|c|c|c|c|c|c|c|c|c|c|}
\hline Variable & Group & $\mathrm{T1}( \pm \mathrm{SD})$ & $\Delta \mathrm{T} 2-\mathrm{T} 1(95 \% \mathrm{CI})$ & $\mathrm{T} 3$ ( \pm SD) & $\Delta \mathrm{T} 4-\mathrm{T} 3(95 \% \mathrm{CI})$ & $\Delta \mathrm{T} 4-\mathrm{T} 1(95 \% \mathrm{CI})$ & $P_{\mathrm{T} 2-\mathrm{T} 1}$ & $P_{\mathrm{T} 4-\mathrm{T} 3}$ & $P_{\mathrm{T} 4-\mathrm{T} 1}$ \\
\hline \multirow{3}{*}{$\begin{array}{l}\text { SBP decline } \\
\text { (mmHg) }\end{array}$} & Control & $6.2 \pm 9.0$ & $-0.7(-8.5$ to 7.1$)$ & $5.0 \pm 8.6$ & $-0.3(-5.2$ to 4.6$)$ & $-1.5(-7.6$ to 4.6$)$ & \multirow{3}{*}{0.635} & \multirow{3}{*}{0.816} & \multirow{3}{*}{0.936} \\
\hline & LMIT & $11.4 \pm 7.3$ & $-2.4(-8.5$ to 3.8$)$ & $8.8 \pm 7.7$ & $-1.6(-5.5$ to 2.3$)$ & $-4.3(-9.1$ to 0.6$)$ & & & \\
\hline & HIT & $10.6 \pm 4.9$ & $-0.5(-8.3$ to 7.3$)$ & $11.0 \pm 7.7$ & -1.7 ( -6.6 to 3.2$)$ & $-1.3(-7.4$ to 4.8$)$ & & & \\
\hline \multirow{3}{*}{$\begin{array}{l}\text { DBP decline } \\
\text { (mmHg) }\end{array}$} & Control & $7.0 \pm 5.7$ & $-1.6(-9.2$ to 6.0$)$ & $6.8 \pm 6.1$ & $-2.3(-6.7$ to 2.1$)$ & $-2.5(-7.9$ to 2.9$)$ & \multirow{3}{*}{0.991} & \multirow{3}{*}{0.561} & \multirow{3}{*}{0.960} \\
\hline & LMIT & $10.9 \pm 5.2$ & $-1.7(-7.8$ to 4.3$)$ & $9.7 \pm 5.6$ & $-0.1(-3.6$ to 3.4$)$ & $-1.4(-5.6$ to 2.9$)$ & & & \\
\hline & HIT & $10.8 \pm 4.3$ & $-2.1(-9.7$ to 5.5$)$ & $11.0 \pm 5.7$ & $-1.2(-5.6$ to 3.2$)$ & $-1.0(-6.4$ to 4.4$)$ & & & \\
\hline \multirow{3}{*}{$\begin{array}{l}\text { Average SBP } \\
(\mathrm{mmHg})\end{array}$} & Control & $121.9 \pm 14.7$ & $0.9(-5.1$ to 6.9$)$ & $122.9 \pm 13.6$ & $0.1(-5.8$ to 6.0$)$ & $1.1(-5$ to 7.2$)$ & \multirow{3}{*}{0.753} & \multirow{3}{*}{$<0.05$} & \multirow{3}{*}{$<0.05$} \\
\hline & LMIT & $120.9 \pm 10.2$ & $2.4(-2.3$ to 7.1$)$ & $123.8 \pm 12.9$ & $-2.0(-6.7$ to 2.7$)$ & $0.9(-4.0$ to 5.7$)$ & & & \\
\hline & HIT & $124.1 \pm 11.8$ & 0.5 ( -0.5 to 6.5$)$ & $126.2 \pm 10.4$ & $-9.5(15.4$ to -3.6$) *+\neq$ & $-7.4(-13.5 \text { to }-1.3)^{*}$ & & & \\
\hline \multirow{3}{*}{$\begin{array}{l}\text { Average DBP } \\
(\mathrm{mmHg})\end{array}$} & Control & $72.6 \pm 11.0$ & $1.4(-3.7$ to 6.5$)$ & $73.0 \pm 10.7$ & $1.9(-2.5$ to 6.3$)$ & $2.3(-3.3$ to 7.9$)$ & \multirow{3}{*}{0.871} & \multirow{3}{*}{$<0.001$} & \multirow{3}{*}{$<0.05$} \\
\hline & LMIT & $72.4 \pm 5.0$ & 2.0 (-2.0 to 6.0$)$ & $74.3 \pm(6.8)$ & $-2.3(-5.8$ to 1.2$)$ & $-0.6(-5.0$ to 3.9$)$ & & & \\
\hline & HIT & $73.7 \pm 8.4$ & $0.8(-4.3$ to 5.9$)$ & $75.2 \pm 7.1$ & $-7.0(-11.4$ to -2.6$) * t \ddagger$ & $-5.5(-11.1$ to 0.1$)$ & & & \\
\hline \multirow{2}{*}{$\begin{array}{l}\text { Average MAP } \\
\quad(\mathrm{mmHg})\end{array}$} & Control & $89.0 \pm 11.7$ & $1.2(-3.9$ to 6.3$)$ & $89.6 \pm 11.1$ & $1.3(-3.2$ to 5.8$)$ & $1.9(-3.6$ to 7.4$)$ & \multirow[b]{2}{*}{0.818} & \multirow[b]{2}{*}{$<0.05$} & \multirow[b]{2}{*}{$<0.05$} \\
\hline & LMIT & $88.6 \pm 5.7$ & $2.1(-1.9$ to 6.2$)$ & $90.7 \pm 8.4$ & $-2.2(-5.8$ to 1.3$)$ & $-0.1(-4.4$ to 4.2$)$ & & & \\
\hline \multirow{3}{*}{$\begin{array}{l}\text { Systolic load } \\
(\%)\end{array}$} & Control & $45.5 \pm 35.8$ & $5.0(-14.6$ to 24.6$)$ & $47.9 \pm 34.5$ & $5.2(-24.9$ to 35.4$)$ & $7.6(-13.2$ to 28.4$)$ & \multirow{3}{*}{0.935} & \multirow{3}{*}{$<0.05$} & \multirow{3}{*}{0.151} \\
\hline & LMIT & $53.7 \pm 33.0$ & $3.0(-12.5$ to 18.6$)$ & $59.4 \pm 34.7$ & $-3.0(-26.9$ to 20.8$)$ & $2.6(-13.8$ to 19.0$)$ & & & \\
\hline & HIT & $58.5 \pm 38.0$ & $1.4(-18.2$ to 21.0$)$ & $77.9 \pm 56.1$ & $-35.9(-66.0$ to -5.7$) * t \ddagger$ & $-16.5(-37.3$ to 4.3$)$ & & & \\
\hline \multirow{3}{*}{ Diastolic load (\%) } & Control & $52.6 \pm 29.3$ & $2.0(-15.4$ to 19.4$)$ & $55.4 \pm 29.4$ & $2.9(-14.2$ to 20.1$)$ & $5.7(-15.7$ to 27.1$)$ & \multirow{3}{*}{0.687} & \multirow{3}{*}{$<0.05$} & \multirow{3}{*}{$<0.05$} \\
\hline & LMIT & $57.6 \pm 21.4$ & $8.0(-5.7$ to 21.8$)$ & $64.7 \pm 28.5$ & $-7.5(-21.1$ to 6.0$)$ & $-0.4(-17.3$ to 16.5$)$ & & & \\
\hline & HIT & $58.0 \pm 24.5$ & $2.6(-14.8$ to 20.0$)$ & $63.3 \pm 17.2$ & $-26.6(-43.8$ to -9.5$) * t \ddagger$ & $-21.3(-42.7$ to 0.1$)$ & & & \\
\hline
\end{tabular}

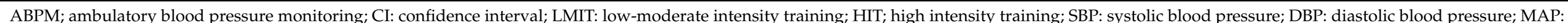

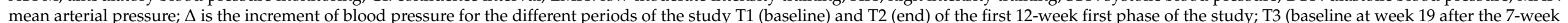

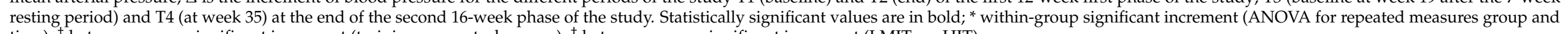
time); ${ }^{+}$between-group significant increment (training vs. control groups); ${ }^{\ddagger}$ between-group significant increment (LMIT vs. HIT). 
Improvement in BP levels during the first 12-week training phase of the study were not obtained, probably suggesting that such duration for a therapeutic training program could be inadequate to achieve the desired effects on hypertensive patients under pharmacological treatment. Other studies have also shown beneficial effects on BP for training periods over 12 weeks [28-30]. However, for the second extended training period of 16 weeks, HIT was more beneficial than LMIT in reducing BP. In a randomized study of 42 individuals with a baseline $\mathrm{BP} \geq 130 / 85 \mathrm{mmHg}$, moderate intensity continuous exercise as compared with high intensity interval exercise did not modify any of the 24-h AMBP monitoring [31]. Moreover, HIT may favor advantageous adaptations of physiopathological variables that contribute to the development of hypertension. Therefore, HIT may be effective in reducing blood pressure, even in a lesser period of time, by increasing of apelin and NOx plasma levels [32]. All these effects together with reduced training time and duration as compared with moderate intensity continuous exercise may have important implications in the management of hypertension [8].

$\mathrm{ABPM}$ recording is a useful tool for the characterization of BP profiles by registering multiple daytime and night-time BP measures, which ensure a more detailed circadian monitoring and avoid diagnosis errors based on a single, isolated daytime measure [33]. Furthermore, registered information allows to estimate variables like $24-\mathrm{h} \mathrm{MAP}$, and to make a detailed characterization of circadian patterns in BP, such as dipper-non-dipper, which has turned to be critical to evaluate cardiovascular morbidity and mortality and first choice tool for the prediction of hypertension-mediated organ damage [13]. Previous studies have postulated a beneficial influence of a regular aerobic activity on strengthening the effect of the SBP and pulse pressure drop at night ("dipping") despite the lack of the influence upon the 24-h SBP [34]. In this study, BP modifications are found in both daytime and night-time BP registers. In fact, a drop of SBP, DBP, and systolic and diastolic loads was noticed during the second phase of the training program, after the resting period. Indeed, both intensities of training are capable to cause such decrease in BP variables, although HIT showed significantly better results for both circadian periods, allowing a reduction of beta-blockers medication in two patients following the prescription of their family physicians.

Ambulatory blood pressure (ABP) variability is a single independent indicator of cardiovascular risk [35]. High daytime SBP variability has been associated with the progression of early carotid atherosclerosis and significantly higher rate of cardiovascular morbid events [36]. Regular aerobic exercise can reduce BP but without a reduction in BP variability [37]. Such phenomenon is comparable to the effects of beta-blockers on BP and $\mathrm{BP}$ variability. Despite the lacking effect on BP variability, exercise should be routinely recommended to hypertensive patients as a basic lifestyle modification that potently reduces BP and elicits a multitude of further cardiovascular benefits [37]. In this study, ABP variability remains unaltered in both intervention groups during both day and night-time AMBP monitoring.

The present findings, however, should be interpreted taking into account the limitations of the study, particularly, the relatively small number of participants initially assigned to the three study groups, and the fact that the number of dropouts was higher in the HIT group. The reasons for a lower rate of compliance with the HIT modality is unknown, although other factors that may had an influence on compliance, such as age, female gender or BMI seem unlikely because significant differences in the distribution of these variables among the study groups were not observed. On the other hand, differences in the use of antihypertensive medication were not found. However, regarding the effect of HIT and LMIT on the study outcomes, similar results were obtained in the analysis of the PP and ITT populations. It should be noted that the training program included the combination of strength and endurance exercises, which have shown to produce greater cardiovascular benefits in hypertension than if endurance or strength training is performed alone [38,39]. However, the independent effect of strength or endurance alone on BP in this study cannot be specified. Finally, the pathophysiological mechanisms by which HIT regulates BP are nu- 
merous, involving effects on cardiorespiratory fitness, endothelial function and its markers, insulin sensitivity, autonomic nervous system activity, arterial stiffness, and blood glucose and lipoproteins [40], outside the scope of discussion of this study. However, additional analyses of parameters such as nitrogen oxides (NOx), apelin or specific lipoproteins and hormones would contribute to identify the underlying mechanisms by which exercise training improves BP.

\section{Conclusions}

In this pilot clinical study, primary care prescription of physical exercise in the framework of a community-based program appears to be a suitable adjunct therapy to control $\mathrm{BP}$ in the management of hypertension. The training intervention divided into two phases of 12 and 16 weeks, respectively, separated by a seven-week resting period, showed beneficial effects in reducing BP in hypertensive subjects under antihypertensive medication. In relation to the intensity of training, HIT was more effective than LMIT in the second phase of the study, but also was associated with a lower compliance rate. The mechanistic background of the positive effects of HIT merits further investigation. Intensity of training should be individually prescribed to improve tolerance to more high intensity exercises.

Supplementary Materials: The following are available online at https:/ /www.mdpi.com/article/10 $.3390 /$ jpm11040291/s1, Table S1: Summary of data from ABPM recordings overall $24 \mathrm{~h}$. Intention to treat analysis.

Author Contributions: Conceptualization, F.J.L.-R. and V.Á.-G.; methodology, F.J.L.-R., A.L.-R., and V.Á.-G.; software, E.G.-S. and M.S.-M.; validation, A.L.-R., E.G.-S., and V.Á.-G.; formal analysis, M.S.M., V.Á.-G., A.L.-R., and F.J.L.-R.; investigation, V.Á.-G., A.L.-R., E.G.-S., and F.J.L.-R.; data curation, F.J.L.-R.; writing—original draft preparation, V.Á-G., and F.C.; writing—review and editing, M.S.-M., A.L.-S., and F.C.; visualization, F.C.; supervision, F.J.L.-R.; project administration, V.Á.-G.; funding acquisition, F.J.L.-R. All authors have read and agreed to the published version of the manuscript.

Funding: We received funds from the Consejo Superior de Deportes (CSD). Ministerio de Cultura y Deporte. Spain. 015/UPR10/12.

Institutional Review Board Statement: The study was conducted according to the guidelines of the Declaration of Helsinki, and approved by the Ethics Committee of UCAM (C231111).

Informed Consent Statement: Informed consent was obtained from all subjects involved in the study.

Data Availability Statement: No new data were created or analyzed in this study. Data sharing is not applicable to this article.

Acknowledgments: This study was possible due to the ACTIVA community program, which was dependent of the "Dirección General de Planificación, Investigación, Farmacia y Atención al Ciudadano from the Consejería de Salud" of Murcia. We thank Marta Pulido, MD, for editing the manuscript and editorial assistance.

Conflicts of Interest: The authors declare no conflict of interest.

\section{References}

1. Dickinson, H.O.; Mason, J.M.; Nicolson, D.J.; Campbell, F.; Beyer, F.R.; Cook, J.V.; Williams, B.; Ford, G.A. Lifestyle interventions to reduce raised blood pressure: A systematic review of randomized controlled trials. J. Hypertens. 2006, 24, 215-233. [CrossRef] [PubMed]

2. Cornelissen, V.A.; Arnout, J.; Holvoet, P.; Fagard, R.H. Influence of exercise at lower and higher intensity on blood pressure and cardiovascular risk factors at older age. J. Hypertens. 2009, 27, 753-762. [CrossRef]

3. Costa, E.C.; Hay, J.L.; Kehler, D.S.; Boreskie, K.F.; Arora, R.C.; Umpierre, D.; Szwajcer, A.; Duhamel, T.A. Effects of high-intensity interval training versus moderate-intensity continuous training on blood pressure in adults with pre- to established hypertension: A systematic review and meta-analysis of randomized trials. Sports Med. 2018, 48, 2127-2142. [CrossRef] [PubMed]

4. Bertani, R.F.; Campos, G.O.; Perseguin, D.M.; Bonardi, J.M.; Ferriolli, E.; Moriguti, J.C.; Lima, N.K. Resistance exercise training is more effective than interval aerobic training in reducing blood pressure during sleep in hypertensive elderly patients. J. Strength Cond. Res. 2018, 32, 2085-2090. [CrossRef] [PubMed]

5. Lima, L.G.; Bonardi, J.T.M.; Campos, G.O.; Bertani, R.F.; Scher, L.M.; Moriguti, J.C.; Ferriolli, E.; Lima, N.K. Combined aerobic and resistance training: Are there additional benefits for older hypertensive adults? Clinics (Sao Paulo) 2017, 72, 363-369. [CrossRef] 
6. Sousa, N.; Mendes, R.; Abrantes, C.; Sampaio, J.; Oliveira, J. A randomized 9-month study of blood pressure and body fat responses to aerobic training versus combined aerobic and resistance training in older men. Exp. Gerontol. 2013, 48, 727-733. [CrossRef]

7. Cornelissen, V.A.; Smart, N.A. Exercise training for blood pressure: A systematic review and meta-analysis. J. Am. Heart Assoc. 2013, 2, e004473. [CrossRef]

8. Boutcher, Y.N.; Boutcher, S.H. Exercise intensity and hypertension: What's new? J. Hum. Hypertens. 2017, 31, 157-164. [CrossRef]

9. Piepoli, M.F.; Hoes, A.W.; Agewall, S.; Albus, C.; Brotons, C.; Catapano, A.L.; Cooney, M.T.; Corrà, U.; Cosyns, B.; Deaton, C.; et al. 2016 European Guidelines on cardiovascular disease prevention in clinical practice: The Sixth Joint Task Force of the European Society of Cardiology and Other Societies on Cardiovascular Disease Prevention in Clinical Practice (constituted by representatives of 10 societies and by invited experts) Developed with the special contribution of the European Association for Cardiovascular Prevention \& Rehabilitation (EACPR). Eur. Heart J. 2016, 37, 2315-2381.

10. Hackam, D.G.; Quinn, R.R.; Ravani, P.; Rabi, D.M.; Dasgupta, K.; Daskalopoulou, S.S.; Khan, N.A.; Herman, R.J.; Bacon, S.L.; Cloutier, L.; et al. Canadian Hypertension Education Program. The 2013 Canadian Hypertension Education Program recommendations for blood pressure measurement, diagnosis, assessment of risk, prevention, and treatment of hypertension. Can. J. Cardiol. 2013, 29, 528-542. [CrossRef] [PubMed]

11. Sharpe, P.A. Community-based physical activity intervention. Arthritis Rheum. 2003, 49, 455-462. [CrossRef] [PubMed]

12. Bock, C.; Jarczok, M.N.; Litaker, D. Community-based efforts to promote physical activity: A systematic review of interventions considering mode of delivery, study quality and population subgroups. J. Sci. Med. Sport 2014, 17, 276-282. [CrossRef] [PubMed]

13. Williams, B.; Mancia, G.; Spiering, W.; Agabiti Rosei, E.; Azizi, M.; Burnier, M.; Clement, D.; Coca, A.; De Simone, G.; Dominiczak, A.; et al. 2018 Practice Guidelines for the management of arterial hypertension of the European Society of Cardiology and the European Society of Hypertension. Blood Press 2018, 27, 314-340. [CrossRef]

14. Olsen, M.H.; Angell, S.Y.; Asma, S.; Boutouyrie, P.; Burger, D.; Chirinos, J.A.; Damasceno, A.; Delles, C.; Gimenez-Roqueplo, A.P.; Hering, D.; et al. A call to action and a lifecourse strategy to address the global burden of raised blood pressure on current and future generations: The Lancet Commission on hypertension. Lancet 2016, 388, 2665-2712. [CrossRef]

15. Garber, C.E.; Blissmer, B.; Deschenes, M.R.; Franklin, B.A.; Lamonte, M.J.; Lee, I.M.; Nieman, D.C.; Swain, D.P. Quantity and quality of exercise for developing and maintaining cardiorespiratory, musculoskeletal, and neuromotor fitness in apparently healthy adults: Guidance for prescribing exercise. Med. Sci. Sports Exerc. 2011, 43, 1334-1359. [CrossRef]

16. López-Román, F.J.; Tornel-Miñarro, F.I.; Delsors-Merida-Nicolich, E.; Fernández-López, L.; Martínez-Ros, M.T.; Garcia Sanchez, E.; López-Santiago, A. Feasibility of implementing a preventive physical exercise programme recommended by general practitioners in cardiovascular risk patients: A pre-post comparison study. Eur. J. Gen. Pract. 2020, 26, 71-78. [CrossRef] [PubMed]

17. Pollock, M.L.; Bohannon, R.L.; Cooper, K.H.; Ayres, J.J.; Ward, A.; White, S.R.; Linnerud, A.C. A comparative analysis of four protocols for maximal treadmill stress testing. Am. Heart J. 1976, 92, 39-46. [CrossRef]

18. Tanaka, H.; Monahan, K.D.; Seals, D.R. Age-predicted maximal heart rate revisited. J. Am. Coll. Cardiol. 2001, 37, 153-156. [CrossRef]

19. Vella, C.A.; Taylor, K.; Drummer, D. High-intensity interval and moderate-intensity continuous training elicit similar enjoyment and adherence levels in overweight and obese adults. Eur. J. Sport Sci. 2017, 17, 1203-1211. [CrossRef]

20. De Feo, P. Is high-intensity exercise better than moderate-intensity exercise for weight loss? Nutr. Metab. Cardiovasc. Dis. 2013, 23, 1037-1042. [CrossRef]

21. Hall, E.E.; Ekkekakis, P.; Petruzzello, S.J. Predicting affective responses to exercise using resting EEG frontal asymmetry: Does intensity matter? Biol. Psychol. 2010, 83, 201-206. [CrossRef]

22. Hartman, M.E.; Ekkekakis, P.; Dicks, N.D.; Pettitt, R.W. Dynamics of pleasure-displeasure at the limit of exercise tolerance: Conceptualizing the sense of exertional physical fatigue as an affective response. J. Exp. Biol. 2019, 222 Pt 3, jeb186585. [CrossRef]

23. Ekkekakis, P.; Hall, E.E.; Petruzzello, S.J. The relationship between exercise intensity and affective responses demystified: To crack the 40-year-old nut, replace the 40-year-old nutcracker! Ann. Behav. Med. 2008, 35, 136-149. [CrossRef]

24. Ekkekakis, P.; Parfitt, G.; Petruzzello, S.J. The pleasure and displeasure people feel when they exercise at different intensities: Decennial update and progress towards a tripartite rationale for exercise intensity prescription. Sports Med. 2011, 41, 641-671. [CrossRef] [PubMed]

25. Hall, E.E.; Petruzzello, S.J.; Ekkekakis, P.; Miller, P.C.; Bixby, W.R. Role of self-reported individual differences in preference for and tolerance of exercise intensity in fitness testing performance. J. Strength Cond. Res. 2014, 28, 2443-2451. [CrossRef] [PubMed]

26. Ekkekakis, P.; Vazou, S.; Bixby, W.R.; Georgiadis, E. The mysterious case of the public health guideline that is (almost) entirely ignored: Call for a research agenda on the causes of the extreme avoidance of physical activity in obesity. Obes. Rev. 2016, 17, 313-329. [CrossRef]

27. Heisz, J.J.; Tejada, M.G.; Paolucci, E.M.; Muir, C. Enjoyment for high-intensity interval exercise increases during the first six weeks of training: Implications for promoting exercise adherence in sedentary adults. PLoS ONE 2016, 11, e0168534. [CrossRef]

28. Guimarães, G.V.; Ciolac, E.G.; Carvalho, V.O.; D'Avila, V.M.; Bortolotto, L.A.; Bocchi, E.A. Effects of continuous vs. interval exercise training on blood pressure and arterial stiffness in treated hypertension. Hypertens. Res. 2010, 33, 627-632. [CrossRef]

29. Rognmo, Ø.; Hetland, E.; Helgerud, J.; Hoff, J.; Slørdahl, S.A. High intensity aerobic interval exercise is superior to moderate intensity exercise for increasing aerobic capacity in patients with coronary artery disease. Eur. J. Cardiovasc. Prev. Rehabil. 2004, 11, 216-222. [CrossRef] [PubMed] 
30. Tjønna, A.E.; Lee, S.J.; Rognmo, Ø.; Stølen, T.O.; Bye, A.; Haram, P.M.; Loennechen, J.P.; Al-Share, Q.Y.; Skogvoll, E.; Slørdahl, S.A.; et al. Aerobic interval training versus continuous moderate exercise as a treatment for the metabolic syndrome: A pilot study. Circulation 2008, 118, 346-354. [CrossRef]

31. Sosner, P.; Gayda, M.; Dupuy, O.; Garzon, M.; Lemasson, C.; Gremeaux, V.; Lalongé, J.; Gonzales, M.; Hayami, D.; Juneau, M.; et al. Ambulatory blood pressure reduction following high-intensity interval exercise performed in water or dryland condition. J. Am. Soc. Hypertens. 2016, 10, 420-428. [CrossRef]

32. Reza-Izadi, M.; Ghardashi-Afousi, A.; Asvadi-Fard, M.; Babaee-Bigi, M.A. High intensity interval training lowers blood pressure and improves apelin and NOx plasma levels in older treated hypertensive individuals. J. Physiol. Biochem. 2018, 74, 47-55. [CrossRef] [PubMed]

33. Banegas, J.R.; Rodríguez-Artalejo, F. Cardiovascular-risk prediction and type of event. J. Hypertens. 2014, 32, 473-474. [CrossRef] [PubMed]

34. Ling, C.; Diaz, K.M.; Kretzschmar, J.; Feairheller, D.L.; Sturgeon, K.M.; Perkins, A.; Veerabhadrappa, P.; Williamson, S.T.; Lee, H.; Grimm, H.; et al. Chronic aerobic exercise improves blood pressure dipping status in African American nondippers. Blood Press Monit. 2014, 19, 353-358. [CrossRef] [PubMed]

35. Mancia, G.; Bombelli, M.; Facchetti, R.; Madotto, F.; Corrao, G.; Trevano, F.Q.; Grassi, G.; Sega, R. Long-term prognostic value of blood pressure variability in the general population: Results of the Pressioni Arteriose Monitorate e Loro Associazioni Study. Hypertension 2007, 49, 1265-1270. [CrossRef]

36. Sander, D.; Kukla, C.; Klingelhöfer, J.; Winbeck, K.; Conrad, B. Relationship between circadian blood pressure patterns and progression of early carotid atherosclerosis: A 3-year follow-up study. Circulation 2000, 102, 1536-1541. [CrossRef]

37. Pagonas, N.; Dimeo, F.; Bauer, F.; Seibert, F.; Kiziler, F.; Zidek, W.; Westhoff, T.H. The impact of aerobic exercise on blood pressure variability. J. Hum. Hypertens. 2014, 28, 367-371. [CrossRef]

38. Ruangthai, R.; Phoemsapthawee, J. Combined exercise training improves blood pressure and antioxidant capacity in elderly individuals with hypertension. J. Exerc. Sci. Fit. 2019, 17, 67-76. [CrossRef] [PubMed]

39. Schroeder, E.C.; Franke, W.D.; Sharp, R.L.; Lee, D.C. Comparative effectiveness of aerobic, resistance, and combined training on cardiovascular disease risk factors: A randomized controlled trial. PLoS ONE 2019, 14, e0210292. [CrossRef]

40. Ciolac, E.G. High-intensity interval training and hypertension: Maximizing the benefits of exercise? Am. J. Cardiovasc. Dis. 2012, $2,102-110$. 